Changing Patterns of Employee Voice:

Case Studies from the UK and Republic of Ireland

Adrian Wilkinson

Loughborough University Business School

Tony Dundon

Department of Management, National University of Ireland, Galway

Mick Marchington

Manchester School of Management, UMIST

Peter Ackers

Loughborough University Business School

Address for correspondence:

Professor Adrian Wilkinson

Loughborough University Business School

Ashby Road

Loughborough

Leicestershire

LE11 3TU

01509228273

a.j.Wilkinson@lboro.ac.uk

Words: 7032 (excluding tables and references) 


\title{
Changing Patterns of Employee Voice: \\ Case Studies from the UK and Republic of Ireland
}

\begin{abstract}
In this paper we examine a wide range of employee voice mechanisms from a total of 18 case studies from the UK and republic of Ireland. We examine how voice is defined by managers and how they link voice with improved economic efficiency. The evidence suggests that employee voice is more extensive in terms of its 'scope' and 'impact' than a decade ago, although the 'level' at which employees have a say remains the preserve of managerial control. The evidence also suggests that the link between voice and organisational performance is problematic. The conclusion argues that organisations now face a diffuse and persistent range of concerns from highly articulate employees. In this respect, managing employee voice will be closely related to managing diversity.
\end{abstract}




\section{INTRODUCTION}

The last decade has seen a growing interest in the notion of employee voice, both from those seeking higher levels of organisational performance and from those desiring better systems of employee representation. The European Directive on Employee Information and Consultation is also likely to strengthen the notion of employee voice. While UK and Ireland have a number of unique and diverse regulatory practices, they both have a long history of voluntarist industrial relations, and both countries are the only two EU member states that do not have a general statutory framework to ensure employee involvement. This will change with the transposition of the EU Directive into domestic legislation by 2005 - or 2008 depending on the size of the undertaking (Hall et al, 2002).

Until 1979, the pattern of employee voice in both Ireland and the UK followed broadly similar trajectories. In the UK more direct and individualistic forms of voice took precedence following the Thatcher assault on trade unions. In Ireland collective bargaining, worker directors on the board of semi-state industries and joint consultation have remained much more prominent. The collective spirit of employee representation in Ireland has even been associated with the phenomenal rates of economic growth (Sabel, 1996; McCartney \& Teague, 1998; Gunnigle, 2001). In the UK also, several studies appear to indicate a positive relationship between voice and organisational performance (Patterson et al, 1997; Sako, 1998; Gollan, 2001; Guest \& Peccei, 2001).

However the relationship between participation and performance has not gone unchallenged. In Ireland, Roche \& Geary (2002) question the extent to which new forms of collaborative production have taken hold, and D'Art and Turner (2002) demonstrate a strong 'them and us' divide between management and workers despite the institutional support for employee participation. Similarly, drawing on the Workplace Employee Relations Survey (WERS) series in the UK, Millward et al (2000: 137) note that perceptions of 'fair and independent voice' seem to be related to the presence of a recognised trade union and union representation on a formal joint consultative committee. 
In this article based on case studies in the UK and Ireland we suggest that employee voice is more extensive in terms of its scope and impact than a decade ago, although the level at which employees have a say remains the preserve of managerial control. However, we also express caution in terms of directly linking voice with sustained organisational performance.

\section{The fRAmeWork AND Research Methods fOR the STUdy}

Voice is a word that has been more widely used in the practitioner and academic literature on HRM and industrial relations in recent years (Beardwell 1998; Sako 1998; Roche, 2000; Benson 2000). In the 'best practice' HRM and high performance literature, voice is seen as a key ingredient in the creation of organisational commitment (Lewin \& Mitchell, 1992; Pfeffer, 1998). Indeed, publications on participation emphasise the importance of giving employees a feeling they are making choices, in both union and non-union settings (Walton 1985; Dundon, 2002; Ackers et al, 2004). Conversely, the alternative strand sees voice in terms of rights, linking this to notions of industrial citizenship - a concept given greater impetus through membership of the European Union.

The word 'voice' was popularised by Freeman and Medoff (1984) who argued that it made good sense for both company and workforce to have a 'voice' mechanism. This had both a consensual and a conflictual image; on the one hand, participation could lead to a beneficial impact on quality and productivity, whilst on the other it could deflect problems which otherwise might 'explode'. Trade unions were seen as the best agents to provide voice as they were independent and would reduce exit.

Given that the subject of voice has attracted interest from a variety of perspectives and disciplines, it is hardly surprising that its meaning has also been interpreted differently by scholars as well as practitioners (Marchington et al, 2001). A framework for employee voice can be seen in Figure 1 below, with voice differentiated along two dimensions. These are (a) direct(based on employees themselves) and indirect (based on a union or collective grouping), and (b) shared and contested agendas. This provides four ideal types: upward problem-solving, grievance processes, partnerships and collective bargaining. Of course these are not 
bald alternatives as organisations can operate on more than one of these dimensions. These two axes are meant to imply tendencies towards, e.g. a shared agenda or contested agenda, rather than absolute differences. Our framework for voice is therefore rather broader and more systematic than those used by most commentators.

\section{FIGURE 1 ABOUT HERE}

The research was conducted between March and June 2001 in a total of 18 organisations. The general approach was a qualitative method given the nature of both the information sought and 'exploratory' character of the research. There was no pre-determined definition of employee voice, and one of the key objectives was to explore managerial conceptions of employee voice, choice and impact on performance. The limitations of the research are that each organisation was visited only once, and interviews were conducted just with managerial respondents. These included the person responsible for HR and other senior managers, such as chief executive, managing director or senior site manager. In addition to this however, access to documentary material (such as employee attitude surveys, mission statements, corporate information and personnel policies) was made available in several organisations.

Although this particular study was exploratory and limited to managerial respondents, it is worth noting that we have had contact with all but four of these organisations through other projects over a sustained period of time. Seven of the cases formed part of our study for the Employment Department in the early 1990s. A further seven have been the subject of other research, either during the last decade or in parallel with other studies - for example, for the UMIST Future of Work project and research funded by the European Regional Development Fund. This provided a degree of knowledge about the organisational context prior to the fieldwork, as well as an understanding of the major employment relations issues at these sites.

Consequently, data collection involved more than a single snapshot visit.

In order to obtain as rounded a picture as possible of employee voice and management choice, the organisations reflect differences in size (medium and large), 
structure (single/multi-site), representative systems (union and non-union) as well as covering a range of sectors of economic activity. These broad contextual factors have been shown to be important discriminators in other research evidence (Cully et al, 1999). Seven of the companies had a partnership agreement with the recognised trade union, two had embarked upon union de-recognition and three employed specific non-union employee consultative committees. Five of the organisations reflected stand-alone, small-to-medium sized enterprises while 13 had operations at more than one site. Another five were classified as multinational with locations in different countries and continents (see table 2).

\section{Defining Voice}

Although some respondents felt that previously they had never heard of the term 'employee voice', most were able to provide a definition to illustrate their understanding of what it meant. A number of respondents felt that it had resonance for them, and they were comfortable with its usage. Principally, most of the managers tended to see voice as synonymous with terms such as 'consultation', 'communication' and 'say'.

There were five broad ways in which the managers spoke about employee voice in general. The responses were analysed after the interviews had been completed and then grouped into categories using the definitions outlined below.

Communication/exchange of views: an opportunity for employees and managers to exchange views about issues, generally on an individual basis but also through a collective consultation process.

Upward problem-solving: an opportunity for employees to provide feedback on specific topics, not so much as a dialogue but more as a way of providing ideas to improve organisational performance.

Collective representation: an opportunity for employee representatives - union or non-union - to communicate the views of the workforce to managers either through partnership or collective bargaining. 
Engagement: a feeling on the part of staff that they are able to express their views to managers in an open environment and that management will provide support to allow this to happen.

Say about issues: the opportunity not just to have a 'voice' on issues but an expectation that these views will be taken into account and may lead to changes in how decisions are made

It will be apparent that the first three categories are concerned with processes, the fourth with feelings and perceptions, and the final category with outcomes. It is therefore quite feasible that a respondent could speak in terms of more than one category during the interviews. Interestingly, not one respondent mentioned 'grievances' as a form of employee voice in their initial definitions. Moreover, even when the issue of 'grievances' was discussed later in the interview, this tended to be viewed by most respondents as a procedural activity that had little to do with their understanding of the term. At most, it was considered marginal to the notion of voice.

Voice as communication was by far the most common immediate response to the question asking managers to explain their understanding of the term 'voice'. The Operations Manager at Bet.com summed up the ideas of many when he said: 'we understand this to mean any form of two-way communication, particularly on an individual basis'. This perspective, that voice is more than one-way downward communication, was echoed by the HR Manager at Eiretel who suggested that:

voice is about corporate communications and the strategy is designed in such a way that all employees can represent their views to management, rather than it just being the other way around. Our aim has been to break down the barriers.

These are clear expressions of managers seeing voice in terms of information exchange and discussion with individual employees rather than through any collective mechanism. It was also apparent from these definitions that employee voice was seen largely in terms of its contribution to improvements in organisational 
performance. At Airflight, for example, it was conceived in terms of employees adding value and enhancing their contribution to organisational goals. Voice was not seen as an opportunity for employees to express dissatisfaction with their working environment or their supervisor's style of management.

It was rare for these respondents to conceive of information exchange through the lens of collectivism, although it was readily apparent from the mechanisms they described in the interviews that many collective forms of voice did exist. Interestingly, the first aspect of voice mentioned by the Managing Director of the small transport company, Easymove Transport, was his relationship with the local shop steward. He noted that 'we have union representation on a friendly basis. We have a general dialogue, and we (the owner and the shop steward) might disappear down the pub at $5 p m$ on a Friday and have a chat about what is going on.' This is hardly the stuff of formal and constitutional industrial relations, however.

There also seemed to be a clear recognition that voice might be different now from what it was ten or 20 years ago. The Personnel Manager at Southern Shoe responded to the initial question by saying:

employees don't get much voice these days! There were times, ten years ago, in the factories when real efforts were made to ensure that regular communications went on with the workforce through weekly team meetings, suggestion schemes, departmental meetings and even whole factory meetings.

Another group of respondents saw voice not so much as a dialogue or two-way exchange of ideas but rather as the transmission of ideas to managers in order to improve organisational performance, in short upward problem solving. Employees were seen as valuable receptacles of knowledge and ideas that could only help to improve performance, and as such were important sources of expertise, as argued by the Managing Director or Leisure Co:

the term has a resonance with me. I started off in the ranks myself and have always been very keen that employees have a view. After all, they are actually 
face-to-face with customers, not the Managing Director, so I rely very much on what they are able to filter up.

Notions of collective representation were not central to the initial definitions of voice. When we asked for specific examples, it was noticeable that a wide range of collective voice mechanisms is in use. One of the large financial services organisations, Retail Bank, used the term 'partnership' in referring both to employees' financial stakes in the company as well as to its more contemporary usage in employee relations. The HR Manager said that 'the union is talking about partnership because the government is seen to be promoting employer-trade union partnerships'. The HR Manager at Whisky Co also felt that 'employee voice' equated with partnership:

I would say that it's partnership in its most adult and consensual form. It's partnership because we want to be with each other and because we recognise the advantages of working constructively with the trade union. The more freeflowing the information in the dialogue, the less there are any surprises and so it's a lot less adversarial.

The most radical and philosophical interpretation of voice came from the Labour Chair of Governors in the school who stressed that 'a collective union voice is a must for our evolution. Each person should have a voice and it does help if the people are organised.' It is also important to note here that collective voice is not just restricted to unionised establishments, but was apparent at quite a number of organisations that operated with staff associations (such as Housing Association) or non-union consultative forums (as at Scotoil and Compucom).

There are structural and psychological aspects to voice, in much the same way that empowerment is seen to constitute both of these (Wilkinson, 2002). The structural aspects can be observed from an examination of systems and practices that operate in an organisation, but this does not ensure that employees either feel that they have a voice or are confident in utilising this voice. Managers at two organisations made specific reference to this aspect of voice. The Chief Executive of Aqua spoke at length about the need for voice to be real and not merely symbolic. He said: 
employee relations is rather like customer relations. It's a bit like treating people in the way that you would like to be treated. This needs to be genuine engagement rather than just tokenism. If you can capture the hearts and minds of people in the business, then very high levels of energy are released. If we think that we can manage organisations in a hierarchical way, we are in for a big shock.

Whilst many of the respondents talked in general terms about the processes of voice, quite a number also insisted that the outcomes of voice were particularly important. The words used varied between 'influence' and 'say', but broadly they coalesced around the notion of employees having some say or influence over policies and practices. We are not seeking to convey the impression that this represents a situation in which changes are led by employees or that their voice is actually 'heard' by managers whilst making decisions. Nevertheless, the distinctive feature of these definitions was that they all related to the potential for employee voice to impact upon outcomes rather just describing the processes that are used in organisations. Many of the managers stressed the importance of informal mechanisms and processes here, rather than just the formal structures that are provided in organisations.

Both the General Manager and the HR Specialist at ConsultancyCo felt that voice was meaningless unless it made an impact. The General Manager suggested that: 'Voice is about having opinions and observations heard. How voice is realised, recognised and acted upon is what matters. There is no "real" voice if it is not listened to'.

\section{DIFFERENT FORMS OF EMPLOYEE VOICE}

Given that seven of the case studies took part in a similar project 10 years ago, there was an opportunity to examine the changing patterns of voice over time. Two findings stood out from this analysis. First, some of the different employee involvement mechanisms found in 1992 had now been recast or fused into more all-embracing upward problem-solving voice mechanisms. There was evidence of less ad hoc choices and that schemes had been more clearly integrated, particularly in terms of employees 'having a say'. The second is representative participation. In many 
cases this was through union representation and collective bargaining, although systems for employee representation in non-union firms, or even the co-existence of union and non-union channels at the same workplace, existed across the case studies. Significantly, the role of trade unions in relation to direct involvement had changed markedly. There was some evidence of derecognition as well as new union recognition agreements, although overall senior managers saw value in working with trade unions and appeared to share information with union representatives at earlier stages in the process.

Table 1 provides data on 'employee voice' for the 18 organisations included in the study. As well categorising the forms of employee voice into the two broad categories identified above, the final column also provides an assessment of the most distinctive practices. It is apparent from table 1 that upward problem-solving is reported as more extensive than representative participation - as we might have expected from other recent studies (Cully et al, 1998; Gill \& Krieger, 1999).

\section{TABLE 1 ABOUT HERE}

\section{Upward problem-solving in practice}

All the organisations employed downward communications in one form or another, with about one-third making use of electronic media to increase the ease by which employees could respond to management or convey their own opinions to senior managers. Not surprisingly, this was more common in the service sector where whitecollar workers (and particularly professionals) formed the bulk of staff. At Eiretel, for example, the US Vice President would often send electronic messages to all staff, a practice that has been copied by other senior managers. The system is used to allow staff to post questions about technical or human resource issues direct to senior managers. Whilst in theory these have to be answered, there was some scepticism about the degree to which the whole process was stage-managed.

Two-way communications are a major form of voice at all the sites. Most of these are relatively standard in format, but it is worth providing a few examples to show how these operate in practice. At the school, there are daily ten-minute meetings before 
teaching commences to allow the Head to brief staff on important issues for the day, such as absenteeism and staff cover, important visitors and new information of relevance to the school. A quite different type of arrangement operates at the transport firm. Here, the Managing Director arranges a meeting every few months on a Sunday morning in a local pub. All drivers are invited, and although they are not paid to attend, the company provides bacon sandwiches and a beer kitty. Middle managers are barred from these meetings, which are attended by the Finance Director and the MD. The Managing Director felt that this represented the best way for him to get information across to staff as well as keep in touch with employee opinion.

The use of employee and attitude surveys are used in about half the organisations studied. Some of these operate at the sites we investigated as part of world-wide benchmarking exercises for the companies as a whole, with the results then being fed back from corporate headquarters back down the management chain to staff on the shop floor or in the office. In these circumstances, it is unlikely that employees (or managers for that matter) feel any ownership of the results, other than as a benchmarking tool through which to secure improvements in performance.

The vast majority of the case studies reported the use of project teams in some form or another. Some of these are central to the operation of the organisation, such as the matrix teams at Compucom and ConsultancyCo that are formed to deal with specific projects and are then disbanded once the job is completed.

\section{Representative participation in practice}

About two-thirds of the organisations had some form of joint consultation operating either at site level or beyond the workplace, compared with about one-quarter for the WERS 1998 sample. JCCs were more common in larger, multi-site workplaces, and about half the unionised workplaces had JCCs compared with all but one of the nonunion firms. At some companies, these had been in existence for a long time, and they followed the fairly standard pattern of regular monthly or quarterly meetings between a number of senior managers and the shop stewards. The activity levels of these meetings varied. At Scotchem, the meetings with the TGWU tend to be 
concerned with fairly trivial items such as 'showers, lockers and overtime levels because things seem to be sorted out at the workplace level.' This sort of 'safety valve' committee was supplemented by the wider meeting incorporating all the unions. These appeared to be more strategic in nature and formed part of the partnership agenda at the plant, as the Manufacturing Director at Scotchem explained:

This is an opportunity to share the slightly longer-term outlook with these guys following the senior management meeting. I talk with them about the manufacturing plan for the next month and what the issues are. It gives the senior stewards a chance to express one or two of their concerns about the future.

Several organisations have specifically set up non-union channels alongside the union framework or include non-union representatives at the same meeting. At Midbank, for example, despite a range of mechanisms to consult with unions - such as the Joint Partnership Meeting - a Staff Council has been established with representatives elected by all staff, whether union or non-union:

The staff council is a consultation forum. It's just giving them information, it's not a negotiating forum or anything.

Significantly, the coexistence of union and non-union forms of employee voice was more than an isolated example. Indeed, joint consultation - in one form or another was widespread at organisations that did not recognise unions for collective bargaining purposes. At Housing Association, a JCC was set up over 20 years ago. The Deputy Director regarded it as:

A mechanism that has stood the test of time, but it has not been widely used by employees for making their voice heard. However, I can probably count out on one hand the number of really contentious issues that have been thrashed out around the table. 
Seven of the cases had some form of partnership scheme in existence, although not all actually termed it that. Perhaps the most extensive and wide-ranging partnership agreement is between Midbank and UNIFI. The key principles of the agreement relate to 'mutuality and inclusiveness, an acceptance that both parties have distinctive but complementary roles, and an acknowledgement that difficult and contentious issues have to be confronted jointly'.

A partnership agreement also operates at Whisky Co under the title 'Working Together'. This used phraseology that is well-known in these sorts of agreement mutuality, joint commitment to organisational performance, acknowledgement of separate interests. A section from the agreement noted that:

The culture (of 'Working Together' in partnership) promotes employee development, participation, flexibility, performance and reward within a framework of excellent communications. The agreement will be the basis of our joint ability to add value to the company's business performance through the creation of an ethical and inclusive environment of opportunity.

European works councils are obviously a relatively new 'voice' structure for most workers in the UK and Ireland. The EWC at Whisky Co came about because the firm is part of a much larger European-owned multinational, that at Eiretel through its part in a large American-owned firm, and those at Scotoil and Southern Shoe due to these UK-owned firms having other sites throughout the rest of Europe. Overall, however, EWCs were seen as a relatively remote mechanism for employee voice; more as something that was required rather than a mechanism that was seen to add value. Eiretel provided two employee representatives for the EWC, but again this was considered to be too 'distant' for it to be meaningful for employees at the Irish plant. Moreover, it was felt that the agenda was rather narrow and minimalist, in line with the perception that the company had been forced to accept an EWC rather than willingly introduce and develop this. In a similar vein, the EWC at Southern Shoe had only recently been introduced and had yet to find a clear focus.

The final form of voice that we consider is collective representation, which existed at about two-thirds of the organisations. Trade unions have always provided a 
channel for independent voice to employers, either through collective negotiations about wages and conditions or through the pursuit of individual employee grievances. As such, collective representation offers an alternative perspective to the forms that have been discussed so far, the vast majority of which are initiated by employers and are more susceptible to potential managerial influence and control. Additionally, whilst most other forms of voice that have been considered thus far are concerned with how employees can contribute - ultimately - to improved organisational performance, collective representation can provide challenges to current priorities and perspectives as well. The impact on organisational performance may also be positive, but this can be indirect.

The form and impact of collective representation varied substantially among the organisations and this depended on, inter alia, the level of membership, the type of unions and managerial attitudes towards collective representation. In the case studies levels of membership varied from very high to relatively insignificant, collective bargaining took place at different levels across the larger organisations, and the number of unions that were recognised varied from one to four. Significantly, while collective representation figured so little in management accounts of voice, employers still regarded unions as a positive force in expressing employee concerns and were prepared to disclose information to representatives much earlier than had been a the case a few years ago.

\section{THE PERCEIVED BENEFITS OF EMPLOYEE VOICE}

Given that isolating cause and effect is problematic, one way in which voice may be seen to impact on employee behaviour and performance is the 'indirect' linkage between practice and outcome. Although our respondents agreed that it was difficult to quantify the impact of voice, there was widespread agreement that employee voice acted as the gateway to a more open and constructive climate. It is this better climate which was then seen to help identify the links between voice and impact. Many of the managers commented that voice contributed to improved performance because it generated a better environment in which to work. The Chief Executive of Aqua articulated this view: 
We are spending plenty of money on [staff] engagement at the moment. We do it because we believe this adds value and what you tend to get is a slightly chaotic challenging world in which people are prepared to say what they think. I think I can prove the impact of voice. It can be seen in terms of performance and the way the business sparkles. The way that people answer letters, deal with customers over the telephone, their feelings of ownership and pride.

This indirect relationship between voice and impact has further support in that the mechanisms used were generally part of a much broader HR agenda. Several respondents commented that in practice voice tended be one of several HR practices -including training, induction, culture change or more open management styles. For example, at Housing Association, employee voice was part of much wider paternalistic and ethical managerial approach of 'treating employees in a decent way':

I don't think we set out to say we will use employees to create a profitable or successful organisation, I think it comes from another angle ... we don't bushwhack them and catch them off guard. It's not the kind of atmosphere we want to generate at all ... If you treat your workforce decently and honestly you will reap the benefits (HR Manager, Housing Association).

When considering any specific or single rationale for why employers bother with voice, then the evidence was less clear. However, what did emerge is a combination of complementary practices, and for simplicity these have been categorised under three headings. The first we have termed employee contributions. Under this, we include employee attitudes and behaviours, loyalty, commitment and co-operative relations, along with employee suggestions. The second theme relates to improvements in the way people are managed, which we have labelled improved managerial systems. This incorporates the managerial benefits from tapping into employee ideas, the informative and educational role of voice along with relations with recognised trade unions. The final theme corresponds to improved performance, as perceived by the managers interviewed. Under this heading we include productivity and individual performance, lower absenteeism and (in a few cases) new business arising from employee voice. 
In reality of course, some of these areas overlap and do not represent discrete bundles but rather simplified patterns of (perceived) impact. For instance, the generation of ideas from a suggestion scheme could shape both the nature and quality of future contributions by employees, but it may also help improve the efficiency and quality of how people are managed. Thus, in reality the precise contours and patterns are likely to be much more complicated, dynamic and uneven.

\section{Employee contributions}

In two-thirds of the case studies, managers reported some improvement in employee attitudes and behaviours as a result of employee voice, albeit to varying degrees. The Customer Service Manager at Bet.com had very strong views that voice does have a positive impact on employee commitment, even though precise details were difficult to quantify:

The business won't function properly: a) if we haven't got people coming in who are committed; and b) more particularly, we've got people who were once committed but we've done something to hack them off. If we're unwittingly doing something that's not getting the best out of people then at least we have the opportunity to put things right and speak to the person.

One interesting finding from our sample related to the 'scope' and 'range' of issues on which employees are able to contribute. For instance, team briefings and top down communications are often associated with more trivial matters, yet we find that voice can impact on a broader set of issues including customer relations, organisational strategies, new services and products to clients, as well as internal work systems. At ConsultancyCo, a voice mechanism called 'strategy days' allowed workers 'a say' over the future direction of the company. Directors first outlined company objectives, market issues and prospective clients to the whole workforce, before employees spent the day in small groups discussing these issues and feeding back ideas to a plenary session that agreed an 'action plan'. At Scotchem, an employee relations workshop was one attempt to bring together union representatives and senior managers to work on issues to do with the process of managing employment relations, including the measurement of staff satisfaction that reflected and reinforced 
new relationships. Similarly, at Scotoil, non-union staff representatives had a wide remit to include agenda items for discussion at the works committee. Examples ranged from proposals for new off shore safety helicopters to improved parking facilities, free lunches, and a new company-wide discipline procedure. The rationale was explained by the Senior Site Manager at Scotoil:

Our employees spend hundreds of thousands of pounds every day to pursue business objectives. Our experience with consultation is that our employees place the same degree of objectivity and professionalism on the issues that they are asked to give their opinions on as they do for their business goals.

Whilst any attempt to unpack voice or draw any causal links to enhanced performance is problematic, there does seem to be a strong pattern to suggest that the range of issues employees contribute towards are far-reaching and extensive. On the whole, our study does not support the idea that voice is confined to trivial matters in order to conjure up an illusion of pseudo-participation. The difficulty is that precise details of cause and effect are almost impossible to disentangle.

\section{Improved management systems}

In addition to improvements arising from employee contributions, there are also spinoffs that are believed to improve people management systems and processes. At Scotchem, it was felt that the greater willingness by staff to challenge issues and decisions around the site had an educative impact for management by improving $\mathrm{HR}$ systems. Also, at City School, an achievement award for improved performance was won, and the Head felt that the School Development Planning day two years ago was one of the major reasons for a change in ethos. At that event, the Head presented information on the school's results and then broke staff into groups to discuss the way forward.

This meant looking at the ethos of the school and trying to work out where we would like to be and how we would get there. The seeds for the improvements were clearly sown at that meeting. 


\section{Organisational performance}

On the whole, improved performance indicators are perhaps the most difficult to define let alone measure. Several studies, such as those by Huselid (1995), Paterson et al (1997), and Guest (1997), suggest that the most appropriate indicators of improved performance include low levels of absenteeism, productivity improvements and better staff retention rates. However, as previously noted, not all of the organisations maintained adequate absence, productivity or retention statistics that allowed independent assessment of the links between voice and performance. As a result we have to rely upon managerial impressions of the relationship between voice and performance, and it may be that superior organisational performance provides the space and resources to experiment with employee voice.

With these limitations in mind, several respondents expressed their belief that there was a clear link between voice and performance. The HR Manager at Scotchem felt that it would be impossible to gain significant improvements without a large element of voice. He was keen to achieve a situation where people wanted to do much more than just come to work, and felt that such an environment directly contributed to low levels of absence and staff turnover. Interestingly, he suggested that a major advantage of voice was that 'it greased the wheels of industry'. In that sense the link between voice and performance has a resonance with other 'indirect' benefits such as a more co-operative environment. The Manufacturing Director at Scotchem also felt there were very clear, tangible benefits that had actually emerged from voice:

quite dramatic and remarkable improvements in quality and productivity, as well as in cost structures at the new plants ... I can see huge differences not just because of the technology, but in the way that people gain advantage from the benefits of the technology and apply it in order to improve performance.

While it was difficult to actually differentiate the impact of employee voice compared with any other aspect of employment relations at each of the organisations, all of the managers felt that, in their experience, voice was a major contributor to the success of other HR polices. At Midbank, voice was a major component of the most recent change programme that was aiming to review and improve the bank's people 
management policies. Introduced during 1999, the first phase of the project covered reward and recognition, roles and behaviours, and performance management. Management workshops and focus groups involved 116 staff at all levels, completed in 1999. Output from these groups was used to develop proposals for a new reward and development structure.

The potential for employee voice to contribute directly to additional business was mentioned several times, particularly at the smaller organisations where employees had some direct contact with customers. At Bet.com for instance, the speed and accuracy with which call centre operatives dealt with customers was viewed as critical for customer satisfaction, and it was argued that this helped to retain existing customers as well as gaining future business. Also, at ConsultancyCo, employee ideas were central to new client contracts and employees were encouraged to come up with new services and products on their own initiative. At Easymove Transport, drivers received a small bonus when they passed on information to the owner about customers and clients that might result in new business.

The major difficulty with evaluating such impacts is they tend to relate to other HR initiatives as well as voice. A number of organisations claimed that voice led to improvements in staff retention and a reduction in absence but this was often linked to a broader package of HR measures rather than voice per se. At ConsultancyCo the central message was corporate culture. The centrality of ethics was a strong feature at Housing Association, whilst at Airflight and HiFi Sounds, customer care was regarded as of paramount importance. Overall, managers were sure that there was a positive relationship between employee voice and performance. However, what remains problematic is that much of the data is perceptual. That is, any voice and performance link is predicated on the managerial assumption 'better performance is good for business' and therefore must be 'good for employees'.

\section{CONCLUSION}

In this study, the majority of definitions of voice provided by managers revolved around the processes rather than being explicitly concerned with outcomes. Few saw voice in terms of collective representation but instead tended to focus on two-way 
communications, an exchange of ideas or upward problem-solving. Some were adamant that it was the opportunity for voice that mattered, and that not too much attention should be placed on the techniques that were in place. In this respect, voice was seen as an informal part of daily operations. If staff felt unable to express their voice, either through a lack of confidence or a belief that it would not be taken seriously, there was little point in having the systems in the first place. The overwhelming impression gained is that voice typically revolves around two-way communications. This is then seen as a way to enhance employee contributions and thus lead to improved levels of performance.

The evidence presented here suggests that the link between voice and performance remains problematic. A key issue is that of evaluation and on whose terms. Should assessments be made in terms of merely having a voice (i.e. the process) or in terms of how things may be changed due to voice (i.e. the outcomes)? If it is the latter, then who gains? None of the organisations in this study claimed that they evaluated the impact of voice initiatives as a whole. Broadly speaking, employee voice operated primarily as a loose and imprecise notion that was seen to contribute to competitive advantage, but also as part of a general and broader package of HR practices. 'Unpicking' its contribution made little sense to these organisations.

Despite these cautions, there does appear to be a more systemic alliance of disparate voice mechanisms than there was ten years ago (Marchington et al, 1992). Two-way communications are now rather less about trivia and more about issues to do with operational outcomes. There is a longstanding academic view that effective worker participation in industry is doomed to fail because of the 'arms-length adversarial' system of industrial relations (Hyman 1995). From this perspective, neither workplace union representatives (focused on job controls and distributive bargaining) nor line managers (concerned to protect management prerogative) are interested in a positive-sum sharing of power that makes for effective employee participation. We found some evidence that this double blockage is becoming a less significant obstacle. In some cases the scope of collective bargaining (in both distributive and integrative terms) incorporated a broader set of strategic policies. A new generation of line managers, union representatives and employees appear more at ease with a set of inclusive (direct and indirect) rather than exclusive (direct versus indirect) voice practices. Managers seem more confident in organising direct 
exchanges of opinion with employees, while union representatives and employees expect them to do so. In this respect, there has been a normalisation of employee voice that transcends the traditional collective-individualist discourse.

While the UK and Republic of Ireland do not represent a single institutional industrial relations space, they are the only two European member states without a statutory framework for employee voice. This will change with the transposition of the EU Directive on Employee Information and Consultation promoting a more sympathetic, if qualified, support for trade union and representative forms of employee voice (Ackers et al, 2004). Moreover, the new citizenship rights agenda promoted by the EU pays particular attention to employee voice and impacts directly on employer choice in this area. Given the range of managerial initiatives assessed in this article, such as voice and partnership, the expectations of many employees have been raised. Indeed, many of the managers we spoke with stressed that employees are now more confident in expressing their views. As this enters the heart of working life and, in the case of voice, gains institutional forms, organisations are increasingly likely to face a diffuse but persistent range of concerns from highly articulate employees. In this respect, managing employee voice will be closely related to managing diversity.

\section{ACKNOWLEDGEMENTS}

The authors would like to acknowledge the support of the Chartered Institute of Personnel and Development (CIPD) for the funding of this research, and in particular the assistance of Mike Emmott. The views expressed in this article are not necessarily those of the CIPD. An earlier version of the article was presented at the Association of Industrial Relations Academics of Australia and New Zealand (AIRAANZ) Annual Conference 2003, Melbourne. 


\section{REFERENCES}

Ackers P., Marchington M., Wilkinson A. and Dundon T. Partnership and Voice, with or without trade unions: Changing UK management approaches to organisational participation in M. Stuart and M. Martinez Lucio, (eds) Partnership and Modernisation in Employment Relations, Routledge, 2004.

Beardwell I. 'Voices on', People Management. May 1998. pp32-36.

Benson J. 'Employee voice in union and non-union Australian workplaces', British Journal of Industrial Relations. Vol. 38, No. 3, 2000. pp453-9.

Cully M., O'Reilly A., Woodland S. \& Dix, G. Britain at Work: As Depicted by the 1998 Workplace Employee Relations Survey. London, Routledge, 1999.

D'Art, D. \& Turner, T., 'An attitudinal Revolution in Irish Industrial Relations: The End of "Them" and "Us", in D. D'Art \& T. Turner (eds), Industrial Relations in the New Economy, Blackhall Press, Dublin, 2002.

Dundon, T. 'Employer opposition and union avoidance in the UK', Industrial Relations Journal, Vol 33 (3), 2002, pp 234-245.

Freeman R. and Medoff J. What do Unions do? New York, Basic Books, 1984.

Gill C. and Krieger H. 'Direct and representative participation in Europe: Recent evidence'. The International Journal of Human Resource Management, Vol. 10, No. 4, 1999. pp572-91.

Gollan, P. 'Be aware of the voices'. People Management. 22 March 2001, p55.

Guest D. 'Human resource management and performance: A review and research agenda'. International Journal of Human Resource Management. Vol. 8, No. 3, 1997. pp263-76.

Guest D. and Peccei R. 'Partnership at work: Mutuality and the balance of advantage'. British Journal of Industrial Relations. June 2001. pp207-236.

Gunnigle, P., 2001, Involvement, Participation and partnership: a review of the debate and some reflections on the Irish context, Mimo, University of Limerick, 2001.

Hall, M., Broughton, A., Carley, M. \& Sisson, K., Works Councils for the UK?, London, Eclipse Group/IRRU.

Huselid M. 'The impact of human resource management practices on turnover, productivity and corporate financial performance'. Academy of Management Journal. Vol. 38, No. 3, 1995. pp635-72.

Hyman R. 'The historical evolution of British industrial relations'. In P. Edwards (ed) Industrial Relations: Theory and Practice in Britain. Oxford, Blackwell, 1995. pp2749.

Lewin D. and Mitchell D. 'Systems of employee voice: Theoretical and empirical perspectives', California Management Review, Vol. 34, No. 3. 1992. pp95-111.

Marchington M., Goodman J., Wilkinson A. and Ackers P. New Developments in Employee Involvement. Employment Department Research Paper Series No 2. HMSO, London. 1992

Marchington, M., Wilkinson, A., Ackers, P. \& Dundon, T. Management Choice and Employee Voice, London, CIPD, 2001.

Millward N., Bryson A. and Forth J. All change at work: British employment relations 1980-1998 as portrayed by the Workplace Industrial Relations Survey Series. London, Routledge. 2000

McCartney, J. \& Teague, P., 'Workplace Innovations in the Republic of Ireland', Economic \& Social Review, Vol 28 (4), 381-99, 1998. 
Patterson M., West M., Lawthom R. and Nickell S. The Impact of People Management Practices on Business Performance. London, Institute of Personnel and Development. 1997

Pfeffer, J., The Human Equation, Harvard Business School Press: Boston, 1998.

Roche, W., 'The End of New Industrial Relations?', European Journal of Industrial Relations, Vol 6 (3), pp261-282, 2000.

Roche, W. \& Geary, J., 'Collaborative Production and the Irish Boom: work organisation, partnership and direct involvement in Irish workplaces', in D. D'Art \& T. Turner (eds), Industrial Relations in the New Economy, Blackhall Press, Dublin, 2002.

Sabel, C., Ireland: local partnerships and social innovation, OECD, Paris, 1996.

Sako, M., "The nature and impact of employee "voice" in the European car components industry, Human Resource Management Journal, Vol 8 (2), 5-18, 1998.

Walton R. 'From control to commitment in the workplace'. Harvard Business Review Vol. 64, No. 3, 1985. pp77-84.

Wilkinson A. Empowerment in M. Warner (ed). International Encyclopaedia of Business and Management ( $2^{\text {nd }}$ Edition), London: International Thomson Learning, 2002, pp. 1720-1730. 
Figure 1: A Framework for Employee Voice

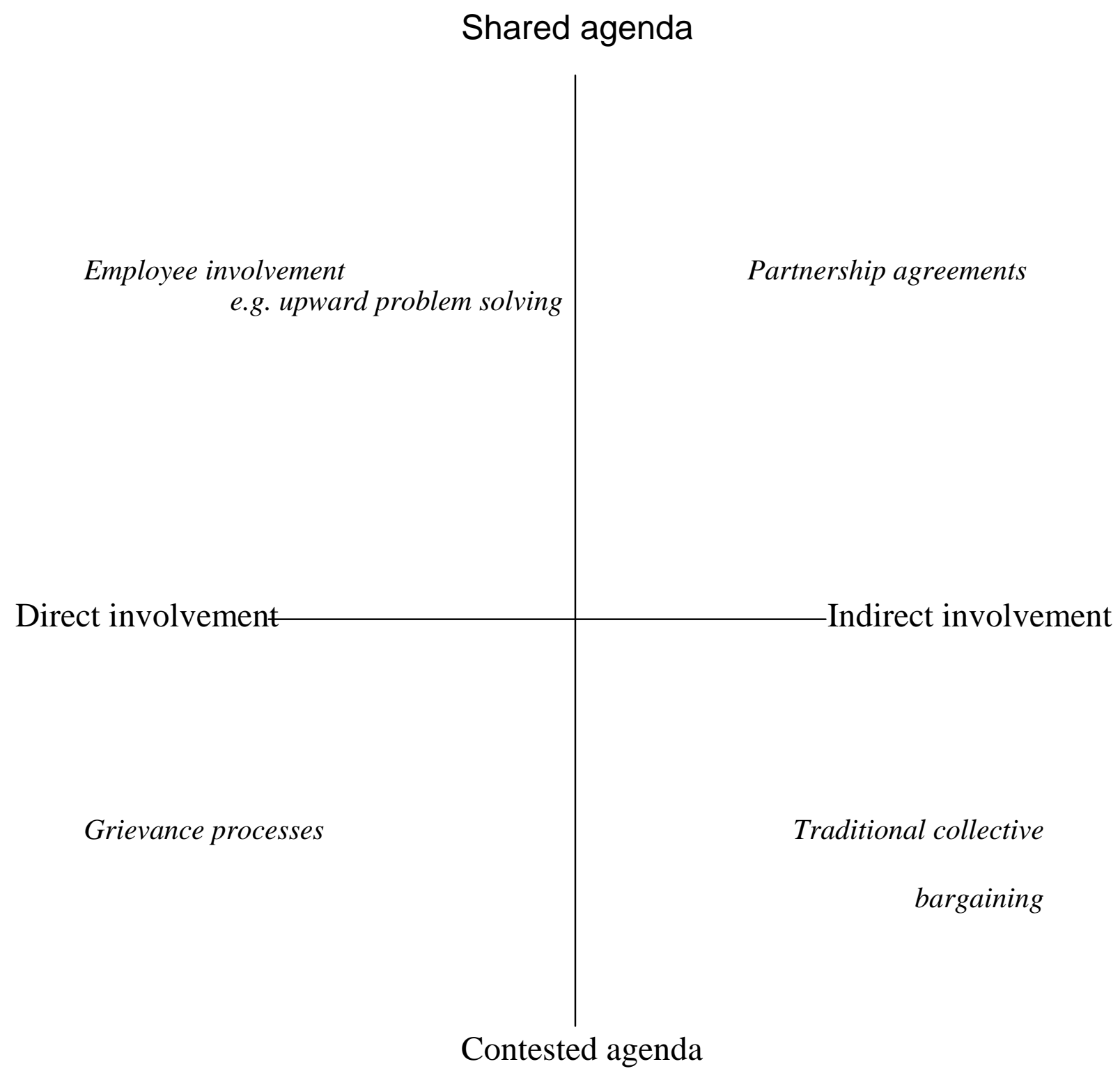



Table 1: Mechanisms for Employee Voice

\begin{tabular}{|c|c|c|c|c|c|c|c|c|c|c|}
\hline & \multicolumn{5}{|c|}{ Upward problem-solving } & \multicolumn{4}{|c|}{ Representative participation } & \\
\hline & $\begin{array}{l}\text { Electronic } \\
\text { media }\end{array}$ & $\begin{array}{c}\text { 2-way } \\
\text { communications }\end{array}$ & $\begin{array}{c}\text { Suggestion } \\
\text { schemes }\end{array}$ & $\begin{array}{l}\text { Attitude } \\
\text { surveys }\end{array}$ & $\begin{array}{c}\text { Project } \\
\text { teams }\end{array}$ & $\begin{array}{c}\text { Joint } \\
\text { consultation }\end{array}$ & $\begin{array}{c}\text { Partnership } \\
\text { schemes }\end{array}$ & $E W C$ & $\begin{array}{c}\text { Collective } \\
\text { representation }\end{array}$ & \\
\hline Organisation & & & & & & & & & & $\begin{array}{l}\text { Distinctive } \\
\text { practices }\end{array}$ \\
\hline Airflight & $\checkmark$ & $\checkmark$ & & & $\checkmark$ & & & & $\checkmark$ & Devolved voice \\
\hline Aqua & & $\checkmark$ & & $\checkmark$ & $\checkmark$ & $\checkmark$ & $\checkmark$ & & $\checkmark$ & Enterprise council \\
\hline Bet.com & & $\checkmark$ & & & $\checkmark$ & & & & $\checkmark$ & Focus groups \\
\hline City School & & $\checkmark$ & & & $\checkmark$ & & & & $\checkmark$ & $\begin{array}{l}\text { Development } \\
\text { planning day }\end{array}$ \\
\hline Compucom & $\checkmark$ & $\checkmark$ & $\checkmark$ & & $\checkmark$ & $\checkmark$ & & & & Works council \\
\hline ConsultancyCo & $\checkmark$ & $\checkmark$ & $\checkmark$ & $\checkmark$ & $\checkmark$ & & & & & Strategy days \\
\hline $\begin{array}{l}\text { Easymove } \\
\text { Transport }\end{array}$ & & $\checkmark$ & $\checkmark$ & & & & & & & Sunday meetings \\
\hline Eiretel & $\checkmark$ & $\checkmark$ & & $\checkmark$ & $\checkmark$ & $\checkmark$ & & $\checkmark$ & $\checkmark$ & Web enablers \\
\hline Hifi Sounds & & $\checkmark$ & $\checkmark$ & $\checkmark$ & $\checkmark$ & $\checkmark$ & & & & $\begin{array}{l}\text { Suggestion } \\
\text { schemes }\end{array}$ \\
\hline Housing Assoc & & $\checkmark$ & $\checkmark$ & & & $\checkmark$ & & & & Non-union JCC \\
\hline LeisureCo & & $\checkmark$ & & & & $\checkmark$ & & & & Liaison committee \\
\hline Midbank & $\checkmark$ & $\checkmark$ & $\checkmark$ & $\checkmark$ & $\checkmark$ & $\checkmark$ & $\checkmark$ & & $\checkmark$ & $\begin{array}{l}\text { Partnership } \\
\text { learning fund }\end{array}$ \\
\hline Retail Bank & $\checkmark$ & $\checkmark$ & $\checkmark$ & $\checkmark$ & $\checkmark$ & $\checkmark$ & $\checkmark$ & & $\checkmark$ & Button-on systems \\
\hline Scotchem & & $\checkmark$ & & & $\checkmark$ & $\checkmark$ & $\checkmark$ & & $\checkmark$ & $\begin{array}{l}\text { Employee relations } \\
\text { group }\end{array}$ \\
\hline Scotoil & & $\checkmark$ & & $\checkmark$ & $\checkmark$ & $\checkmark$ & & $\checkmark$ & & Consultative forum \\
\hline Southern Shoe & & $\checkmark$ & & & & $\checkmark$ & $\checkmark$ & $\checkmark$ & $\checkmark$ & Company assembly \\
\hline Weave Co & & $\checkmark$ & & $\checkmark$ & $\checkmark$ & & $\checkmark$ & & $\checkmark$ & $\begin{array}{l}\text { Improvement } \\
\text { teams }\end{array}$ \\
\hline Whisky Co & & $\checkmark$ & & $\checkmark$ & $\checkmark$ & $\checkmark$ & $\checkmark$ & $\checkmark$ & $\checkmark$ & $\begin{array}{l}\text { Working together } \\
\text { groups }\end{array}$ \\
\hline
\end{tabular}


Table 2: Background data on all organisations

\begin{tabular}{|c|c|c|c|c|c|c|c|}
\hline Organisation & $\begin{array}{c}\mathbf{N} \\
\text { employees }\end{array}$ & $\begin{array}{l}\text { Multi- } \\
\text { national }\end{array}$ & $\begin{array}{l}\text { Multi } \\
\text {-Site }\end{array}$ & SME & Sector & $\begin{array}{l}\text { Key Informants } \\
\text { interviewed }\end{array}$ & Background/Market Context \\
\hline Airflight & 2,500 & & $\checkmark$ & & $\begin{array}{l}\text { Transport and } \\
\text { communications }\end{array}$ & $\begin{array}{l}\text { HR Director } \\
\text { Head of Cabin } \\
\text { Crew }\end{array}$ & $\begin{array}{l}\text { Airflight was established about ten years ago, and grown substantially } \\
\text { through a series of company acquisitions. It de-recognised the TGWU and } \\
\text { recognised BALPA for pilots. }\end{array}$ \\
\hline Aqua & 1,700 & & $\checkmark$ & & Water & $\begin{array}{l}\text { HR Director } \\
\text { Chief Executive } \\
\text { Other HR } \\
\text { managers }\end{array}$ & $\begin{array}{l}\text { Aqua is a regional water company with over } 100 \text { sites that has experienced } \\
\text { significant change. Numbers employed have declined by about } 25 \% \text { over } \\
\text { the past } 5 \text { years, although Aqua has retained a stable market share. There } \\
\text { are four recognised trade unions with } 67 \% \text { membership (GMB, TGWU, } \\
\text { AEEU and the largest, UNISON). }\end{array}$ \\
\hline Bet.com & 120 & & & & $\begin{array}{l}\text { Call centre } \\
\text { betting }\end{array}$ & $\begin{array}{l}\text { Customer Service } \\
\text { Manager }\end{array}$ & $\begin{array}{l}\text { Bet.com was founded in the 1960s and is now a call centre for sport } \\
\text { betting. The company has experienced significant decline in market share } \\
\text { and workforce size, having employed over } 3000 \text { people at its peak in the } \\
\text { late 1970s. USDAW is the recognised trade union with about } 72 \% \\
\text { membership. }\end{array}$ \\
\hline City School & 60 & & & & Education & $\begin{array}{l}\text { Head Teacher } \\
\text { Chair of School } \\
\text { Governors }\end{array}$ & $\begin{array}{l}\text { The school is based in London. There are about } 650 \text { students aged between } \\
\text { 3-11, and the workforce is evenly divided between teaching and support } \\
\text { staff. The management team comprises of the head teacher, a deputy and } \\
\text { one senior teacher, and the Chair of Governors is closely involved in the } \\
\text { running of the school. Three trade unions are recognised (NUT, NAHT } \\
\text { and UNISON). }\end{array}$ \\
\hline Compucom & 220 & & $\checkmark$ & $\checkmark$ & $\begin{array}{l}\text { Hi-tech } \\
\text { engineering }\end{array}$ & $\begin{array}{l}\text { Personnel } \\
\text { Manager }\end{array}$ & $\begin{array}{l}\text { Compucom was founded in } 1982 \text { and manufactures CCTV technologies. It } \\
\text { has a small niche market for digital security and surveillance systems. The } \\
\text { workforce is spread across } 5 \text { continents, with about } 90 \text { people employed at } \\
\text { the technical hub and head office in Manchester. In } 1997 \text { about } 60 \text { people } \\
\text { were made redundant when all manufacturing operations re-located to } \\
\text { Malta. }\end{array}$ \\
\hline ConsultancyCo & 290 & $\checkmark$ & $\checkmark$ & $\checkmark$ & $\begin{array}{l}\text { Computer and } \\
\text { security } \\
\text { consultancy }\end{array}$ & $\begin{array}{l}\text { HR Manager } \\
\text { Senior Office } \\
\text { Manager }\end{array}$ & $\begin{array}{l}\text { ConsultancyCo specialises in computer software and security consultancy } \\
\text { services. One owner founded the company in 1992, and it has grown on } \\
\text { average by 30\% a year and has sites in London, Edinburgh, Dublin and a } \\
\text { head office in Manchester. About 70\% of the workforce are consultants } \\
\text { with the remaining 30\% support staff. }\end{array}$ \\
\hline
\end{tabular}




\begin{tabular}{|c|c|c|c|c|c|c|c|}
\hline $\begin{array}{l}\text { Easymove } \\
\text { Transport }\end{array}$ & 50 & & & $\checkmark$ & Road haulage & $\begin{array}{l}\text { Owner and } \\
\text { Managing } \\
\text { Director }\end{array}$ & $\begin{array}{l}\text { Easymove is a family run road haulage firm with a site in Northern } \\
\text { England. The bulk of staff have a long employment tenure, and the } \\
\text { company recognises URTU for bargaining and representation. Financial } \\
\text { turnover has doubled during the last three years. }\end{array}$ \\
\hline Eiretel & 98,000 & $\checkmark$ & $\checkmark$ & & $\begin{array}{l}\text { IT/ Tele- } \\
\text { communications }\end{array}$ & HR Manager & $\begin{array}{l}\text { Eiretel is a Canadian owned computer software and telecommunications } \\
\text { company with employees in } 150 \text { countries. The site visited is in the } \\
\text { Republic of Ireland, which employs about } 800 \text { people, mainly professional } \\
\text { and technical engineers. At the time of the research Eiretel announced a } \\
\text { global redundancy programme of } 1500 \text { jobs. SIPTU is the only recognised } \\
\text { trade union for } 110 \text { manual operators. }\end{array}$ \\
\hline HiFi Sounds & 350 & & $\checkmark$ & $\checkmark$ & Retail & $\begin{array}{l}\text { HR \& Training } \\
\text { Manager } \\
\text { Branch Manager }\end{array}$ & $\begin{array}{l}\text { The company operates in the hi-fi retail market with } 43 \text { outlets, a head } \\
\text { office and warehouse. Commercial growth has been through finding a } \\
\text { niche market for discounted products with shops on the fringe of high } \\
\text { street shopping locations. }\end{array}$ \\
\hline $\begin{array}{l}\text { Housing } \\
\text { Association }\end{array}$ & 300 & & & $\checkmark$ & House letting & $\begin{array}{l}\text { Personnel } \\
\text { Manager } \\
\text { Deputy Director }\end{array}$ & $\begin{array}{l}\text { Housing Association is a 'not-for-profit' housing association established } \\
\text { over } 100 \text { years ago to manage a company housing estate for a large } \\
\text { paternalist employer. It has grown since the } 1980 \text { s from a workforce of } 150 \\
\text { to } 300 \text { and now provides a wider range of services, including some } \\
\text { sheltered housing and care homes. }\end{array}$ \\
\hline Leisure Co & $\begin{array}{l}50 \\
\text { permanent } \\
400 \text { casual }\end{array}$ & & & & Theme park & $\begin{array}{l}\text { HR Manager } \\
\text { Managing } \\
\text { Director }\end{array}$ & $\begin{array}{l}\text { Leisure Co is over 10-years old and has had a relatively stable market } \\
\text { share during that time, employing mainly non-unionised seasonal workers, } \\
\text { with the bulk of the workforce (about } 400 \text { ) recruited during the summer } \\
\text { months. }\end{array}$ \\
\hline Midbank & 4000 & & $\checkmark$ & & $\begin{array}{l}\text { Financial } \\
\text { services }\end{array}$ & $\begin{array}{l}\text { Head of Personnel } \\
\text { HR Manager } \\
\text { Line Manager }\end{array}$ & $\begin{array}{l}\text { Midbank is over } 100 \text { years old and has expanded its services and market } \\
\text { over the last decade. Despite significant organisational change and } \\
\text { restructuring over the last decade, the workforce numbers have remained } \\
\text { relatively stable. There is a partnership agreement with UNIFI. }\end{array}$ \\
\hline Retail Bank & 30,000 & & $\checkmark$ & & $\begin{array}{l}\text { Financial } \\
\text { services }\end{array}$ & $\begin{array}{l}\text { Personnel } \\
\text { Manager } \\
\text { Communications } \\
\text { Manager }\end{array}$ & $\begin{array}{l}\text { Retail Bank has its origins in the } 19^{\text {th }} \text { century, operating in the financial } \\
\text { services market. Over the last } 5 \text { years market share has increased with new } \\
\text { services and a focus on selling. A trade union is recognised for bargaining } \\
\text { purposes, with about } 30 \% \text { membership. }\end{array}$ \\
\hline Scotchem & 750 & $\checkmark$ & $\checkmark$ & & $\begin{array}{l}\text { CHEMICAL } \\
\text { MANUFACTURIN } \\
\text { G }\end{array}$ & $\begin{array}{l}\text { HR Manager } \\
\text { Manufacturing } \\
\text { Director } \\
\text { Managing } \\
\text { Director }\end{array}$ & $\begin{array}{l}\text { Scotchem is one of the leading firms in its market and has had a stable } \\
\text { workforce for some time. The TGWU, AEEU and MSF are recognised, } \\
\text { and union density is about } 60 \% \text { overall, but higher amongst manual } \\
\text { employees. Scotchem is part of a large European owned multinational } \\
\text { company which has a large degree of autonomy in how it manages } \\
\text { employment relations }\end{array}$ \\
\hline
\end{tabular}




\begin{tabular}{|l|l|l|l|l|l|l|l|}
\hline Scotoil & 100,000 & $\checkmark$ & $\checkmark$ & & $\begin{array}{l}\text { Oil and gas } \\
\text { exploration }\end{array}$ & $\begin{array}{l}\text { HR Manager } \\
\text { 2 x Senior } \\
\text { Business Unit } \\
\text { Managers }\end{array}$ & $\begin{array}{l}\text { Scotoil employ over people in 100 countries, and in the UK the company } \\
\text { has a high market share for its product. The site visited employs about } \\
\text { 3000 staff, with around 1,200 working on oil platforms. Scotoil, like } \\
\text { Scotchem, is part of a large multinational company which has a large } \\
\text { degree of autonomy in how it manages employment relations }\end{array}$ \\
\hline Southern Shoe & 11,500 & & $\checkmark$ & & $\begin{array}{l}\text { Retail and } \\
\text { manufacturing }\end{array}$ & $\begin{array}{l}\text { Personnel } \\
\text { Manager }\end{array}$ & $\begin{array}{l}\text { The company employs about 3,500 in manufacturing and 8,000 in retail, } \\
\text { mostly part-time. The company has been reorganised over the last decade } \\
\text { with manufacturing sites closed in the UK and acquisitions made in } \\
\text { Germany and Slovakia, along with satellite operations in Portugal and sub- } \\
\text { contracting in India and Vietnam. There is high market competition for low } \\
\text { cost production. The focus of this study is on manufacturing. }\end{array}$ \\
\hline Weave Co & 2,500 & $\checkmark$ & $\checkmark$ & & $\begin{array}{l}\text { Carpet } \\
\text { manufacturing }\end{array}$ & $\begin{array}{l}\text { HR Manager } \\
\text { Production } \\
\text { Director }\end{array}$ & $\begin{array}{l}\text { Weave Co is a family-owned carpet manufacturer with a two hundred-year } \\
\text { history. Following a bad spell in the early 1990s the company has now } \\
\text { expanded its operations globally, with around 50\% of the workforce UK- } \\
\text { based. There is 80\% trade union membership. }\end{array}$ \\
\hline Whisky Co & 200 & $\checkmark$ & $\checkmark$ & & Distillers & Head of HR & $\begin{array}{l}\text { Whisky Co operates across seven sites, with a growing share of the export } \\
\text { (mainly US) market. With a merger and the restructuring process the } \\
\text { TGWU was de-recognised with the GMB as the single union recognised. } \\
\text { The company is keen on the creation of a new culture that incorporates } \\
\text { employee voice. }\end{array}$ \\
\hline
\end{tabular}

